\title{
Identification of Urop11, a novel leptin-modulated gene that is upregulated in the hypothalamus of mice with virus-induced obesity
}

\author{
O Verlaeten ${ }^{1,2,3,4}$, C Casery ${ }^{1,2,3,4}$, S Cavagna ${ }^{1,2,3,4}$, D Naville ${ }^{1,5}$, P Giraudon ${ }^{1,2,3,4}$, \\ M F Belin ${ }^{1,2,3,4}$, M Begeot ${ }^{1,5}$ and A Bernard ${ }^{1,2,3,4}$ \\ ${ }^{1}$ University Lyon1, F-69372, Lyon, France \\ ${ }^{2}$ INSERM U433, 69372, Lyon Cedex 08, France \\ ${ }^{3}$ Neurobiologie Expérimentale et Physiopathologie, Faculté de Médecine R Laennec, rue Guillaume Paradin, Lyon Cedex 08, France \\ ${ }^{4}$ IFR 19 Hôpital Neurologique, Boulevard Pinel, 69394 Lyon cedex 03, France \\ ${ }^{5}$ INSERM U 418, Faculté de Médecine R Laennec, 69372 Lyon Cedex 08, France
}

(Requests for offprints should be addressed to A Bernard; Email: abernard@lyon.inserm.fr)

\begin{abstract}
Obesity results from disturbances of tightly regulated interactions between the nervous, endocrine, and metabolic systems that can be caused by external factors, such as viral infections. A mouse model of obesity induced by brain infection with a morbillivirus, canine distemper virus, allowed us to identify obesity-related genes. Using a subtractive library for the hypothalamus, the main brain structure regulating energy homeostasis, we identified a new gene on mouse chromosome 19 which we named upregulated obese product (Urop) 11 and, which has no homology with any known mRNA. A step-by-step molecular approach allowed us to isolate the full-length mRNA, predict the protein sequence, and identify consensus sites. Urop11 was mainly detected in the hypothalamus and adipocytes, and was dramatically upregulated in these central and peripheral structures in obese mice. Urop11 was also expressed in human neural and lymphoid samples and its expression seemed to be regulated by the state of lymphocyte activation. Interestingly, Urop 11 expression was strongly upregulated both in vivo in mouse hypothalamus and in vitro in mouse neural cell lines, after leptin treatment. Taken together, our data show that Urop11 is a target of leptin, the satiety factor produced by adipocytes, in physiological and pathological conditions, including obesity. This new gene can be considered a key molecule in the hypothalamic integration pathway and demonstrates the importance of Urop11 as a target of leptin action.
\end{abstract}

Journal of Molecular Endocrinology (2007) 38, 3-17

\section{Introduction}

The maintenance of body weight around a set point requires a long-term balance between energy intake and expenditure, and depends on tightly regulated interactions between the nervous and the endocrine systems. Obesity, a pathological result of energy homeostasis deregulation, is thought to be a complex disorder caused by multiple environmental and genetic factors or following a hypothalamic lesion. However, one overlooked possibility is that obesity may have an infectious origin. Several viruses have been reported to cause obesity in animal models following central nervous system infection (Bernard et al. 1983, Herden et al. 2000, Dhurandhar 2001, Lyons \& Nagashima 2002). Animal models have emphasized the role of viral infection in the etiology of human obesity (Dhurandhar et al. 1997, 2000, 2002) and provided a better knowledge of the molecular changes associated with obesity. In order to investigate brain damage leading to obesity, we used our well- characterized mouse model of obesity induced by canine distemper virus (CDV; Bernard et al. 1983, 1999), a virus closely related to human measles virus. Interestingly, in infected mice, the neuroadapted strain of CDV predominantly targets the hypothalamus, the brain structure regulating energy homeostasis (Harrold 2004) and known to be a key site for the integration of central and peripheral signals, including leptin, a satiety factor produced by adipocytes, that act via specific hypothalamic receptors (Elmquist et al. 2005). Deregulation of the neural pathways coordinating these molecular signals could undoubtedly lead to profound neuronal changes, which could result in obesity. We have previously shown that CDV infection leads to altered expression of hypothalamic neuropeptides implicated in obesity (Verlaeten et al. 2001, Griffond et al. 2004), decreases the expression of the functional leptin receptor $\mathrm{Ob}-\mathrm{Rb}$ in the hypothalamus of obese mice (Bernard et al. 1999), and markedly alters the cytokine and protease content of the hypothalamus (Khuth et al. 2001). Hypothalamic 
infection may therefore cause neuronal loss or transcriptional changes of genes involved in food intake and energetic metabolism. To obtain a better understanding of changes in the hypothalamus, we used a subtractive library to identify molecules involved in virus-induced obesity. Hypothalamic mRNA profiles in CDV-infected lean and obese mice were compared, and one gene, named upregulated obese product (Urop) 11, was selected because of the magnitude of the expression increase and the novelty of the sequence. Urop11 fulllength mRNA was obtained and sequenced, the predicted amino acid sequence and central and peripheral localization were determined, and its physiological relevance to obesity analyzed in non-virus-induced obesity model $(o b / o b, d b / d b$, high fat diet (HFD)). Furthermore, leptin regulation of Urop11 expression was examined in vivo and in vitro. Our data show that Urop11, a novel gene, is regulated both in vivo and in vitro by leptin, and is mainly expressed in hypothalamic neurons involved in energy homeostasis, which are implicated in the development or maintenance of obesity. Its presence in human lymphoid samples emphasizes its relevance in human immune pathway.

\section{Materials and methods}

\section{Experimental schedule}

\section{Virus}

The neuroadapted CDV strain $\left(10^{5} \mathrm{PFU} / \mathrm{ml}\right)$ obtained from the Onderstepoort strain serially passaged in suckling mouse brain was used.

\section{Animals}

(i) Four-week-old female Swiss or SV129 mice (Harlan, France) were injected intracerebrally with brain homogenates from either CDV-infected neonatal mice or non-infected neonatal mice and were used for RT-PCR, western blot, immunocytochemistry (ICC), and in situ hybridization (ISH) studies. The mice were housed according to EEC (86/609/EEC) and French (Decree 87-848) animal care regulations with food and water and available ad libitum; the HFD mice received special food (Moraes et al. 2003).

(ii) Four-week-old male C57Bl/6J mice (IFFA-CREDO, L'Arbresle, France), control and obese mice (HFD; Moraes et al. 2003) were used for quantitative reverse transcription (Q-RT)-PCR experiments. Briefly, mice were acclimated for a week with standard chow A04 (UAR, Villemoisson-sur Orge, France) at $24^{\circ} \mathrm{C}$ and allowed to feed ad libitum, lights for $12 \mathrm{~h}$ per day from $0630 \mathrm{~h}$; they were then divided into two groups: one with standard chow $=$ control $(\mathrm{C})$ and another with HFD $(36 \%$ lipids ref TD99249) from Harlan-Tecklad (Madison, WI,
USA) $=$ HFD mice. After 7 weeks of each diet, each group was divided into two subgroups: one subgroup of each group received an Alzet osmotic pump (Alza Corp, Palo Alto, CA, USA) that delivered $10 \mathrm{mg}$ /day recombinant leptin and the other subgroup received pumps with the diluent PBS. Animals were killed after 1-week leptin or vehicle infusion. Hypothalamus was collected and immediately frozen in liquid nitrogen and kept at $80^{\circ} \mathrm{C}$ until use. Mice were clearly obese about 5 weeks after HFD (up to $20 \%$ more than C mice). After 8 weeks, the weight gain of HFD mice was twofold higher when compared with $\mathrm{C}$ mice (11 vs $6 \mathrm{~g}$ ), the percentage of body fat was $27.9 \%$ (HFD) when compared with $10.9 \%$ (C) using dual-energy X-ray absorptiometry, and both the plasma leptin and insulin levels increased (six- and twofold respectively).

\section{Experimental design}

As described (Bernard et al. 1999), infected mice develop acute encephalitis during the active hypothalamic viral replication stage at $7-17$ days postinoculation (dpi) and a substantial proportion of the surviving mice become obese at 4-13 months postinoculation (mpi), with a body weight $\geq 50 \mathrm{~g}$ and leptin levels up to $35 \mu \mathrm{g} / \mathrm{ml}$ when compared with about $30 \mathrm{~g}$ and $7 \mu \mathrm{g} / \mathrm{ml}$ respectively in controls. Non-obese surviving mice are referred to as infected lean mice.

\section{Cell culture}

The mouse N1E115 (ATCC) and hypothalamic neuronal GT1-7 (Mellon et al. 1990, Wetsel et al. 1991, Sandberg \& Low 2005) cell lines were plated onto poly-L-lysine-coated (Sigma) plastic flasks as described previously (Bencsik et al. 1997). At 50-70\% confluence, some of the cells were treated with $100-500 \mathrm{ng} / \mathrm{ml}$ recombinant $16 \mathrm{kDa}$ mouse leptin (Tebu) for 1-4 days and were then processed for western blotting, ICC, or RT-PCR. GT1-7 cell line was obtained from immortalization of hypothalamic GnRH neurons by genetically targeted tumorigenesis in transgenic mice using the promoter of the GnRH gene. The N1E115 cell line was established from a murine neuroblastoma (Amano et al. 1972).

\section{Tissue preparation}

At various times after inoculation (7-17 dpi and 4-13 mpi), mice were deeply anesthetized and perfused with ice-cold $0 \cdot 1 \mathrm{M}$ PBS (pH 7·4; intra-aortic route). For ISH and ICC, the brains, either untreated or fixed by intraaortic perfusion with $1-4 \%$ paraformaldehyde (PFA), were removed, frozen, and stored at $-80{ }^{\circ} \mathrm{C}$ until used to prepare serial $16 \mu \mathrm{m}$ coronal sections (SuperFrost/Plus, Menzel-Glaser, VWR International France, Fortenay-Sous-Bois, France). For western blots, 
cell lysates from infected and non-infected mice (7-14 dpi) and from neural cell lines were used. For RNA extraction, brain structures dissected according to precise anatomical landmarks and adipocytes were collected. RNAs were prepared from the hypothalamus of HFD (HFD) obese mice and age-matched controls (same genetic background) with or without leptin infusion (Moraes et al. 2003), and from untreated and leptintreated N1E115 and GT1-7 mouse neuronal cells as well. For human samples, RNA was extracted from neural (DEV) or immune (C8166, C91PL, CEM, MT4) cell lines $\left(10^{6}\right.$ cells) as already described (Szymocha et al. 2000). For RT-PCR, sham-inoculated and CDV-infected mice were killed during the early stage of infection ( $7-17 \mathrm{dpi}$ ) and sham-inoculated, infected asymptomatic, infected paralyzed, infected pre-obese, and infected obese mice were killed during the late stage of infection (4-13 mpi).

\section{RNA preparation}

RNA from homogenized brain structures, peripheral tissues, and neuronal cell lines was extracted using RNAzol (Bioprobe, Montreuil, France), or alternatively using Trizol (Invitrogen, Life Technologies) according to the manufacturer's protocols. The residual genomic DNA was removed (DNase-free, Ambion, Cambridgeshire, UK) and the RNA was quantified (Lab-on-Chip; Agilent Technologies, Santa Clara, CA, USA). The total RNA used for RACE-PCR was carefully examined for genomic contamination by attempting to amplify intronic sequences by PCR and Southern blotting.

\section{Suppression subtraction hybridization (SSH) and reverse northern blot screening (RNB)}

SSH (Diatchenko et al. 1996) was used to characterize the pattern of cellular gene responses to CDV infection. Hypothalamic mRNAs (50 ng total RNA) from an obese CDV-infected mouse at 5 mpi ('tester', $73 \mathrm{~g}$ ) and an agematched infected lean mouse ('driver', $31 \mathrm{~g}$ ) from the same littermate were compared using SMART PCR cDNA synthesis kits and PCR-Select cDNA subtraction kits (both from ClonTech-Takara Bio Europe, Saint-Germain-enLaye, France) according to the manufacturer's protocol. Differentially expressed transcripts were selected by RNB using ${ }^{32} \mathrm{P}$ cDNA probes from the tester and driver amplified RNA (aRNA; Verlaeten et al. 2001) and sequenced (GenomExpress, Meylan, France). Identification was attempted by a homology search of the GenBank, Ensembl, RIKEN, and TIGR DNA databases.

\section{mRNA quantification}

RT was performed using $500 \mathrm{ng}$ DNA-free reversetranscribed total RNA $\left(1.5 \mathrm{~h} / 42^{\circ} \mathrm{C}\right)$, oligo $(\mathrm{dT})_{12-18}$, and MuLV (Invitrogen). Q-RT-PCR (LightCycler, Roche) was performed using FastStart DNA Master SYBR Green I (Roche) and U11-Es and U11-Er primers and cyclophilin $(\mathrm{CyP})$ primers (Table 1) and reaction conditions of $95^{\circ} \mathrm{C} / 10 \mathrm{~min}$, followed by 45 cycles of $95^{\circ} \mathrm{C} / 10 \mathrm{~s}, 60{ }^{\circ} \mathrm{C} / 5 \mathrm{~s}$, and $72^{\circ} \mathrm{C} / 10 \mathrm{~s}$. Urop $11 \mathrm{mRNA}$ levels were expressed as relative units normalized to CyP mRNA levels and the data analyzed by the Student's

Table 1 Name, accession numbers, and sequences of primers (except primers from suppression subtraction hybridization provided by the manufacturer)

\begin{tabular}{|c|c|c|c|}
\hline & Accession number & Name & Sequences \\
\hline \multicolumn{4}{|l|}{ Target } \\
\hline 18S RNA & X00686 & $18 S-s$ & TGCAAAGCTGAAACTTAAAGGA \\
\hline \multirow[t]{2}{*}{ Cyclophilin } & 50620 & CyP-s & ATAATGGCACTGGCGGCAGG \\
\hline & & CyP-r & CTTCAGTGAGAGCAGAGATTACAAGG \\
\hline \multirow[t]{6}{*}{ Urop11 } & AJ558021 & Es & CAAAGCTACAGGAGGGCTACA \\
\hline & & $\mathrm{Er}$ & TTATGGGGTGGGTTTA \\
\hline & & $\mathrm{Lr}$ & TCTTGTCCTGCACTGCACTGTATTCCT \\
\hline & & Ks & GGCAAGGGTAGTAGGGGCTGA \\
\hline & & & TCTTGTCCTGCACTGTATTCCT \\
\hline & & & TGCATTGCTTTCCAGACAAGGTGTGA \\
\hline ABPA1 & AK032261 & & TGCAAAGCTGAAACTTAAAGGA \\
\hline & & & TCGTTCGTTATCGGAATTAACC \\
\hline & & & GTCCTTTTCCACCCAAGTGA \\
\hline SOCS-1 & NM_009896 & & CTTAACCCGGTACTCCGTGA \\
\hline & & & GAGGTCTCCAGCCAGAAGTG \\
\hline
\end{tabular}


$t$-test and the Mann-Whitney test, a $P$ value of $<0.05$ being considered significant.

\section{Identification of full-length Urop11 mRNA and cDNA library screening}

The original Urop11-351 bp clone identified by SSH was labeled with $\left[\alpha_{-}{ }^{32} \mathrm{P}\right] \mathrm{dCTP}(3000 \mathrm{Ci} / \mathrm{mmol}$, NonaPrimer kit, Gibco) and the labeled clone used to probe a $\lambda$ Triplex mouse brain cDNA library (ClonTech). The single positive $880 \mathrm{bp}$ clone isolated was sequenced. RACE-PCR was then performed on mouse hypothalamus total RNA (GeneRacer; ClonTech), using the manufacturer's protocol. For $5^{\prime}$ end analysis, the U11 GSP, U11-L, designed from the original SSH sequence, and U11-P3r located near the $5^{\prime}$ end of the previously isolated Urop11 triplex sequence, were used for nested amplification. The $3^{\prime}$ end of the Urop11 mRNA was identified by $3^{\prime}$ RACE using the U11-Es primer as the GSP. All PCR products were cloned (XL TOPO cloning kit; Invitrogen) and sequenced (GenomExpress).

\section{Bioinformatic analysis}

The GenBank (NCBI), Ensembl (Wellcome Trust Sanger Institute), and EST (RIKEN, TIGR) libraries were used. ORF motifs were identified using ORF finder (National Center for Biotechnology Information (NCBI)), ATGpr (HRI of Japan), and NetStart 1.0 (Centre de Biochimie Structurale (CBS), Montpellier, France). Polymerase II (Pol II) promoter sites were predicted using Promoter 2.0 Prediction Server (CBS), Neural Network Promoter Prediction (NNPP2.1), and Dragon Promoter Finder1.3. Transcription factor binding sites were localized using MATCH (TRANSFAC Professional 5.1 database). Protein motifs were identified using InterproScan (EMBL) and PSORT II. Post-translational modifications were predicted using Prosite patterns (Expasy), NetOGlyc 2.0 server, and NetPhos 2.0 server (CBS).

\section{In situ hybridization}

Two purified Urop11 PCR products (T7-Er/Es or Er/ T7-Es, 253bp; Table 1) were separately transcribed to obtain sense and reverse 11dig-UTP-labeled cRNAs (DIG RNA labeling kit; Roche Diagnostic). Brain sections were incubated with each probe separately at $59{ }^{\circ} \mathrm{C}$ overnight $(500 \mathrm{ng} /$ slide in: $50 \%$ formamide, $195 \mathrm{mM} \mathrm{NaCl}, 10 \mathrm{mM}$ Tris-HCl $(\mathrm{pH} 7 \cdot 5), 5 \mathrm{mM}$ $\mathrm{NaH}_{2} \mathrm{PO}_{4}, 2 \mathrm{H}_{2} \mathrm{O}, 5 \mathrm{mM} \mathrm{Na} \mathrm{HPO}_{4}, 5 \mathrm{mM}$ EDTA, $1 \times$ Denhart solution, and $125 \mathrm{mg} / \mathrm{ml}$ yeast tRNA), then sequentially washed in buffer $(1 \times$ SSC $(0 \cdot 15 \mathrm{M} \mathrm{NaCl}$ and $0.015 \mathrm{M}$ sodium citrate $(\mathrm{pH} 7 \cdot 0)$ ), $50 \%$ formamide, and $0.1 \%$ Tween 20) and maleic acid, $\mathrm{NaCl}$, Tween (MABT) solution (150 mM NaCl, $100 \mathrm{mM}$ maleic acid,
$190 \mathrm{mM} \mathrm{NaOH}$, and $0 \cdot 1 \%$ Tween $20(\mathrm{pH} 7 \cdot 5))$. Sections were then incubated overnight at room temperature with alkaline phosphatase-conjugated anti-dig antibodies (Roche Diagnostic), diluted in the ratio of 1:1000 in blocking solution, and extensively washed at room temperature in MABT solution and $\mathrm{NaCl}$, Tris, Magnesium, Tween (NTMT) solution (100 mM NaCl, $100 \mathrm{mM}$ Tris- $\mathrm{HCl}(\mathrm{pH} 9 \cdot 5), 50 \mathrm{mM} \mathrm{MgCl}_{2}$, and $0 \cdot 1 \%$ Tween 20). Bound antibodies were detected by incubation with $45 \mu \mathrm{g} / \mathrm{ml} \mathrm{NBT}$ and $175 \mu \mathrm{g} / \mathrm{ml}$ 5-bromo-4chloro-3-indolyl phosphate (BCIP) at $37^{\circ} \mathrm{C}$ in the dark for $20 \mathrm{~min}-24 \mathrm{~h}$.

\section{Immunocytochemistry}

Cells expressing Urop11 protein were identified using polyclonal antibodies against Urop11 obtained by intradermal injection of a rabbit with the predicted antigenic peptide ${ }^{17}$ NH2-CSE-NNT-LFH-LPR-YRN-CONH2 ${ }^{32}$ (Covalab, Villeurbanne, France) coupled to KLH on days 1, 21, and 42, followed by s.c. injection on day 63 . Blood samples taken on days $0,32,54,73,94$, and 111 were tested for antibody by ELISA (CovaTest). IgG was purified from the day 111 sample using a protein A column. Coronal mouse brain sections ( $16 \mu \mathrm{m}$ thick) were treated to eliminate non-specific labeling due to endogenous biotin (Blocking kit, Vector, Systems Inc., Richardson, TX, USA), extensively washed with PBS, $0 \cdot 3 \%$ Triton X-100, and incubated for 3 days at $4{ }^{\circ} \mathrm{C}$ with an optimal dilution of the protein A-protein purified IgG (1:500 in PBS, $0 \cdot 1 \%$ Triton X-100, and 1\% BSA: PBS-T-BSA). After several washes, the sections were sequentially incubated at room temperature with biotinylated anti-rabbit IgG antibodies (Jackson Immuno Research Laboratories, Suffolk, UK; 1:5000 in PBS-T-BSA; $2 \mathrm{~h}$ ), avidin-biotin-peroxidase complex (ABC, Vectastain Elite kit, Vector; 1:500 in phosphate buffer saline-Tween-Bovine Serum Albumin (PBS-T-BSA); $30 \mathrm{~min}$ ), and DAB staining solution (2 $\mathrm{mg}$ in $10 \mathrm{ml} 50 \mathrm{mM}$ Tris $\left.(\mathrm{pH} 7 \cdot 6), 0 \cdot 02 \% \mathrm{H}_{2} \mathrm{O}_{2}\right)$. Pre-immune serum from the immunized rabbit was used as the control. The NiE1115 and GT1-1 cell lines were fixed in cold acetone, and then treated as above.

\section{Western blotting of neural tissues for Urop11-p110 expression}

Dissected hypothalamus and spinal cords or neural cell pellets were sonicated $(100 \mathrm{~Hz}, 5-10 \times 10 \mathrm{~s})$ on ice in lysis buffer (20 mM Tris (pH 7.4), $1 \mathrm{mM}$ EDTA, $5 \mathrm{mM}$ EGTA, $10 \%$ sucrose, and a protease inhibitor cocktail (Complete $1 \times$; from Roche Diagnostics)), samples $(20-40 \mu \mathrm{g}$ protein estimated using the Bio-Rad DC protein assay) were then heated for $5 \mathrm{~min}$ at $95^{\circ} \mathrm{C}$ in $0 \cdot 125 \mathrm{M}$ Tris (pH 6.8), 2\% SDS, $20 \%$ glycerol, $0 \cdot 02 \%$ bromophenol blue, 0.2 M 1,4 dithio-DL-treitol (DDT), 
subjected to SDS-PAGE $(10-15 \% ; 2 \mathrm{~h} / 100 \mathrm{~V})$, and electro transferred (50 $\mathrm{min} / 100 \mathrm{~mA})$ to a nitrocellulose sheet (Schleicher \& Schuell, Brentford, UK). The blots were blocked $(1 \mathrm{~h} /$ room temperature in $5 \%$ defatted milk in PBS ( $\mathrm{pH} 7 \cdot 4)$, containing $0 \cdot 1 \%$ Tween 20), then incubated overnight at $4{ }^{\circ} \mathrm{C}$ with anti-Urop 11 antibodies diluted in TPBS buffer $(150 \mathrm{mM} \mathrm{NaCl}, 12 \mathrm{mM}$ $\mathrm{Na}_{2} \mathrm{HPO}_{4}, 2 \mathrm{mM} \mathrm{KH} \mathrm{PO}_{4}(\mathrm{pH} 7 \cdot 4)$, and $0 \cdot 1 \%$ Tween 20 ), washed twice with TPBS buffer, and incubated for $1 \mathrm{~h}$ at room temperature with anti-rabbit IgG antibodies (Jackson) diluted in the ratio of 1:50 000 in TPBS buffer. The blots were then developed using the $\mathrm{ECL}^{+}$ detection system (CovaLight reagent, Covalab) according to the manufacturer's protocol and exposed to a photographic film ( $\beta \max$, Amersham). For the adsorption experiment, anti-Urop11 antibodies (1:800) were incubated for $1 \mathrm{~h}$ at room temperature with 100 $500 \mathrm{mg} / \mathrm{ml}$ Urop11-p110 peptide prior to use.

Cell fractionation was performed according to the manufacturer's recommendations (ProteoExtract Subcellular Proteome Extraction Kit; Calbiochem), and the various cell extracts treated as above.

\section{(si)-RNA-mediated gene silencing}

Three 21-oligonucleotide small interfering (si)-RNA duplexes (1-CCA GCA GCA GCA GAA TTA-G(d)TT; 2-TCA GCA ACC AGG AAT GCA-U(d)TT; and 3-TTA GAA CTG TGA GTC TCA -A(d)TT; Eurogentec) were designed to target the coding sequence of Urop11. Mouse neural cells $\left(1 \cdot 10^{6}\right.$ cells in $100 \mu \mathrm{l}$ Nucleofector solution $\mathrm{V}$ ) were gently mixed with $2 \mu \mathrm{g}$ (si)-RNA or an (si)-RNA negative control duplex (OR-0030-NEG05), then nucleoporation was performed following the manufacturer's recommendations (Amaxa Biosystems, Gaithersburg, MD, USA) after optimizing the reaction conditions. One milliliter of pre-warmed Dulbecco's modified Eagle's medium containing $10 \%$ fetal calf serum (FCS) and $100 \mu \mathrm{g} / \mathrm{ml}$ streptomycin/penicillin was added to the transfected cells, which were then incubated for $24 \mathrm{~h}$ at $37^{\circ} \mathrm{C}$ in a $5 \% \mathrm{CO}_{2}$ atmosphere. Urop11 expression was analyzed in total cell lysates.

\section{Results}

\section{Identification of Urop11 as a new gene that is upregulated in the hypothalamus of obese CDV-infected mice}

\section{Selection of Urop11 by subtractive analysis}

Eighty cDNA clones, identified by SSH analysis of hypothalamic mRNA from infected obese (tester) and infected lean (driver) Swiss mice, both belonging to the same set of infection experiment, were gridded onto several nylon filters and successively probed with labeled
aRNA from both original populations (mRNA from either obese or lean mice). Figure $1 \mathrm{~A}$ shows a representative result for filters spotted with clone numbers 11-36, while Fig. 1B shows the obese mRNA/lean mRNA band ratio for the same clones. Several cDNAs were found to be expressed at least twice as strongly in the obese hypothalamus (Fig. 1B). Of these, five cDNAs for Upregulated Obese Products, Urops 11, 12, 14, 26, and 32 , which were upregulated respectively, 20-, 3-, 12-, 6-, and 8-fold in the obese hypothalamus, were sequenced and the sequences deposited in the NCBI library as AJ441054, AJ0001700, BE949470, AJ457095, and AJ457094 respectively. Urop12 was identified as neuroserpin mRNA and Urop14 matched a mouse expressed sequence tags (EST), but the other three did not match known genes. Because of the strong upregulation and the novelty of the sequence, we focused on the Urop 11 cDNA. To characterize the gene and its products, we used molecular biological and computational methods to obtain the full-length sequence, localize consensus sites, and predict the protein sequence.

\section{Cloning of full-length Urop11 by cDNA library screening, RNA ligase mediated-rapid amplification of $c D N A$ ends (RLM-RACE) analysis, and computational analysis}

Screening of the mouse brain Triplex library with the Urop11 sequence obtained by SSH (331 bp) identified a longer sequence of $880 \mathrm{bp}$ perfectly overlapping the original clone. As no open reading frame (ORF) was identifiable, we performed RACE-PCR using U11-genespecific primer (GSP) to clearly identify the $5^{\prime}$ and $3^{\prime}$

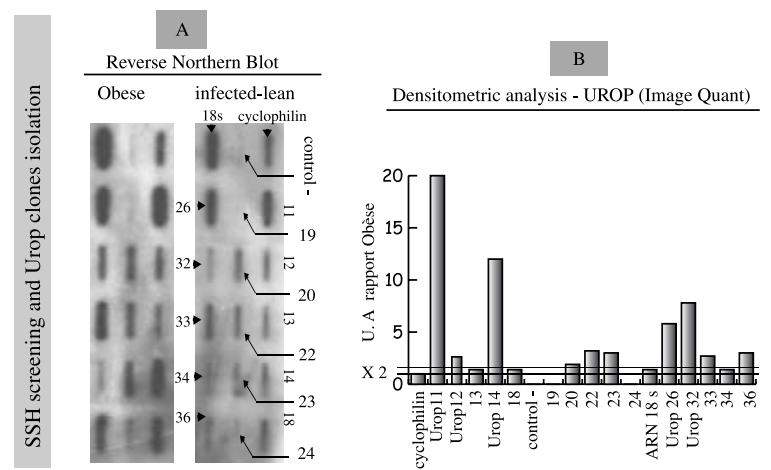

Figure 1 SSH screening and reverse northern blot (RNB). (A) The amplicons isolated following SSH analysis were gridded in the same order onto two nylon membranes, which were then hybridized with ${ }^{32} \mathrm{P}$-labeled aRNA from either an obese-infected mouse (left panel) or a lean-infected mice (right panel). The clone number and arrow indicate the position of the clones. 18S RNA and cyclophilin were used as controls for normalization. (B) Densitometry analysis of the hybridized membranes (image Quant). Clone expression was normalized to that of 18SRNA and cyclophilin and defined as upregulated in the obese mouse when expression was increased by at least twofold. The five clones showing greater upregulation $(11,12,14,26$, and 32) were selected and named Urop (upregulated obese product). 
extremities of U11 mRNA. Sequencing of the longest $5^{\prime}$ RACE-PCR product in combination with the overlapping sequence isolated by $3^{\prime}$ RACE gave a cDNA sequence of $4309 \mathrm{bp}$ (Accession AJ558021). Two
Urop11-GSP primers, U11-Zr and Urop11-Lr (Table 1), localized at each end of this sequence were designed and used to amplify the complete sequence (Fig. 2). This cDNA contained two polyadenylation sites

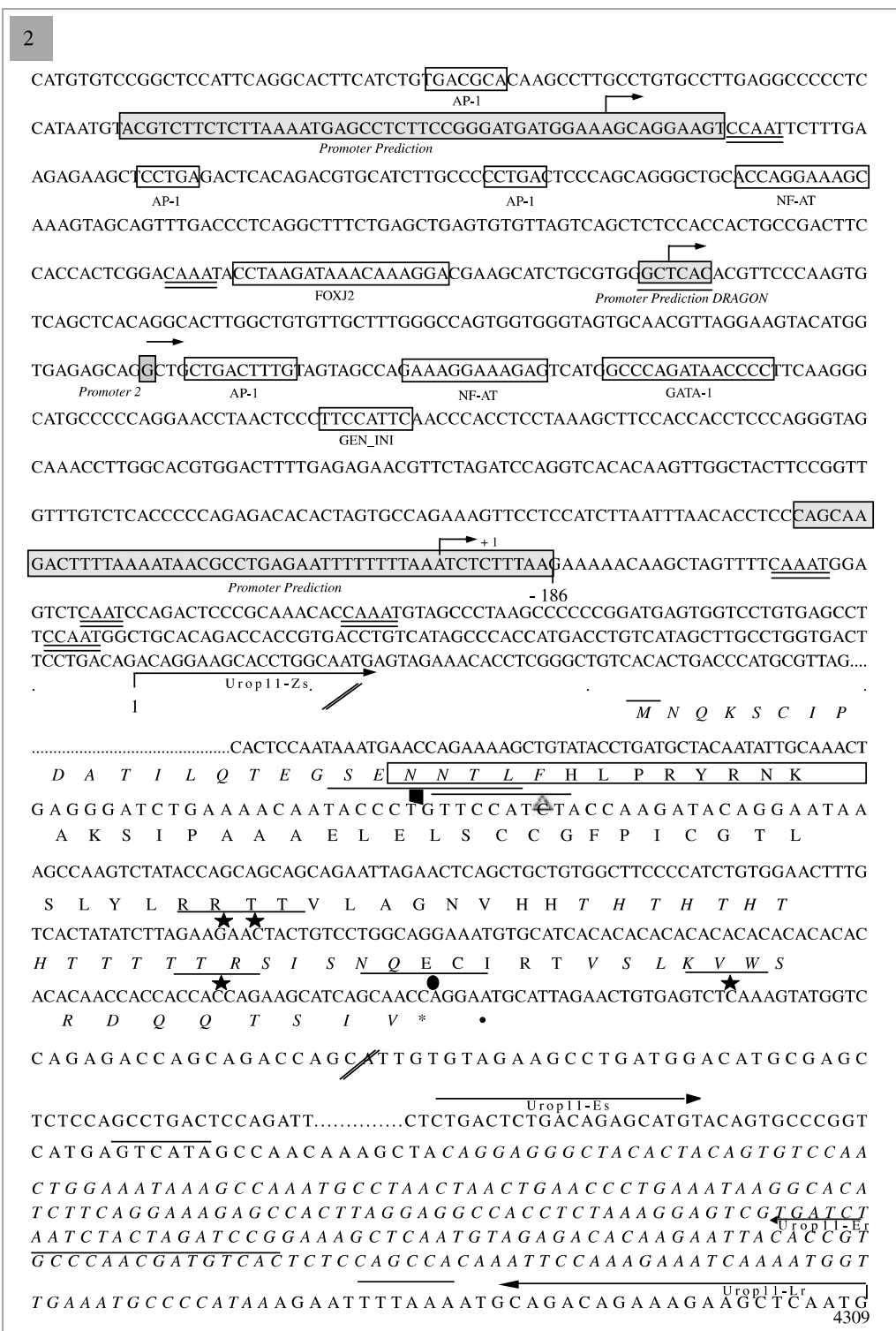

Figure 2 Urop11 cDNA, Urop11-p110 protein, and predicted promoter sites. The sequence of the Urop11 mRNA (AJ558021) is shown in the bottom panel and promoter predictions using NNPP.1.0, Dragon, and Promoter 1.0 software are shown in the top panel. In the top panel, potential promoters are shown in shaded boxes, the putative transcriptional start site $(+1)$ closest to the Urop11-Zs primer (upstream sequence isolated by RACE-PCR) is indicated by an arrow, potential CAAT boxes are double underlined, and transcriptional factor binding sites (MATCH) are shown boxed. In the bottom panel, the Urop11-p110 protein sequence is given and the synthetic peptide used to immunize the rabbit is shown boxed. Predicted post-translational sites are underlined and indicated as follows: $N$-glycosylation (triangle), protein kinase phosphorylation (star), cAMP phosphorylation (double stars), casein kinase II (dot), and $\mathrm{N}$-myristoylation (square). Predicted 'hot loops' for disordered protein are shown in italics. The cRNA probe used for ISH, obtained using the Urop11 primer pair Es-Er, is shown in italics. The polyadenylation site is shown in bold underlined. 
located 25 and 290 nucleotides from the predicted polyA tail. Computational analysis identified a continuous ORF coding for a 110 amino acid protein (Uropp110) with an estimated molecular mass of $12291 \mathrm{Da}$ (ORF Finder, ATGpr, NetStart 1.0; accuracy >95\%). Several possible post-translational modification sites $(N$ glycosylation, cAMP phosphorylation, protein kinase $\mathrm{C}$ phosphorylation, CK2 phosphorylation, and myristylation) were identified, as well as linear motifs for disordered protein ('hot loops'). A search using the basic local alignment search tool (BLAST) program revealed no significant nucleotide homology with any other genes or EST from available public databases. Surprisingly, using public database libraries and computational tools, we found a perfect match between the entire Urop11 sequence and the sequence of the fourth intron of the mouse amyloid $\beta 4$ precursorbinding protein A1 gene ( $A B P A 1$, Accession number AK032261) consisting of 12 exons covering $43 \mathrm{~kb}$ on mouse chromosome 19. The Urop11 messenger located inside the ABPAl genomic sequence was expressed independent of ABPA1 mRNA (RT-PCR experiments, data not shown). As RACE-PCR was performed on genomic-free total RNA checked for absence of DNA, we assumed that the Urop11 sequence was not genomic contamination. To strengthen the accuracy of the ORF prediction, we analyzed the genomic sequence of the fourth intron of ABPA1 between the sequence upstream of the Urop11 cDNA and the ABPAl exon number 3 in order to identify polymerase II promoter and transcription factor binding sites. Neural Network Promoter Prediction software (Pedersen \& Nielsen 1997, Reese 2001) clearly identified two 51-nucleotide initiation consensus sequences starting 1971 and 2612 nucleotides upstream of the Urop11-p110 ORF (99\% accuracy) and 186 nucleotides upstream of the $5^{\prime}$ end sequence isolated by RACE-PCR. A similar prediction was obtained using Promoter 2.0 (Knudsen 1999) and Dragon Promoter Prediction (Bajic et al. 2002) software (65 and 98\% accuracy respectively), which picked out two RNA Pol II promoters between the predicted NPPP promoter positions (Fig. 2). Three weak signals (1, 2, and $5 \mathrm{~kb}$ ) on northern blots (not shown) suggested the existence of Urop11 messengers of different sizes.

\section{Identification of Urop11-p110 protein}

As the bioinformatic analysis suggested a putative Urop11 protein (Urop11-p110), we investigated this by western blotting using a rabbit antiserum raised against a synthetic peptide designed from the deduced sequence. A protein larger than expected (about $35 \mathrm{kDa}$ ) was detected in the mouse hypothalamus and spinal cord (Fig. 3A) and, to a lesser extent, in other brain structures (data not shown). Incubation of the antiserum with the Urop11-p110 synthetic peptide prior immunodetection resulted in a dramatic decreased signal, showing that binding was peptidespecific (Fig. 3A). The data obtained using immunoprecipitation (IP) emphasized the accuracy of Urop11 protein (Fig. 3B). In order to verify the relation between Urop11 protein and mRNA, we performed western blot analysis after (si)-RNA-mediated silencing of the Urop11 gene in the GT1-7 hypothalamic cell line. As shown in Fig. 3C, (si)-RNA1 and (si)-RNA2 reduced Urop11 protein expression by up to $40 \%$ (Image Quant analysis) when compared with the negative control duplex (scramble), and this was associated with reduced mRNA expression (Fig. 3D). Surprisingly, the molecular weight of Urop11 in cell culture (panels 1-5) was larger than the expected size (panel 6, $75 \mathrm{kDa}$ apparent molecular weight versus $35 \mathrm{kDa}$ in tissue). The detection of the $70-75 \mathrm{kDa}$ to a lesser extent (IP data Fig. 3B) points out its conformational complexity. In an attempt to address the function of Urop11, we next performed a subcellular fractionation, which demonstrated the presence of the Urop11 protein mainly in the cytosolic and membrane/organelle fractions. A very weak expression was also seen in the nucleic fraction, whereas the cytoskeleton extract was devoid of the Urop11 protein (Fig. 3E).

\section{Localization of Urop11}

To understand the function of Urop11, we investigated its localization in the brain by ISH using an anti sense riboprobe and by ICC using Urop11-p110-specific antibodies. Labeling was seen in numerous hypothalamic nuclei, being especially strong in the arcuate nuclei (Fig. 4A2), and the labeled neural cells were symmetrically distributed in both hemispheres (Fig. 4A1). In addition to neurons, oligodendrocytes were identified according to their shape and location in brain structures (ZI, corpus callosum) known to contain mostly oligodendrocytes as body cells (Fig. 4A5). The distribution of Urop11 protein was in agreement with the mRNA results, as a subset of hypothalamic neurons being strongly stained (Fig. 4B1); higher magnification showed staining of the cytoplasm and processes (Fig. 4B2). No labeling was seen using either the sense riboprobe or the preimmune rabbit serum (Fig. 4A3 and B3-B4). We further demonstrated the presence of Urop11 protein at the cellular level using ICC, labeling being mainly seen in the cytoplasm and perinuclear area of GT1-7 cells (Fig. 3F). This cellular localization was also confirmed using the fractionation experiment. It is of interest to note that Urop11 mRNA is also constitutively expressed in mouse extra-hypothalamic structures, 

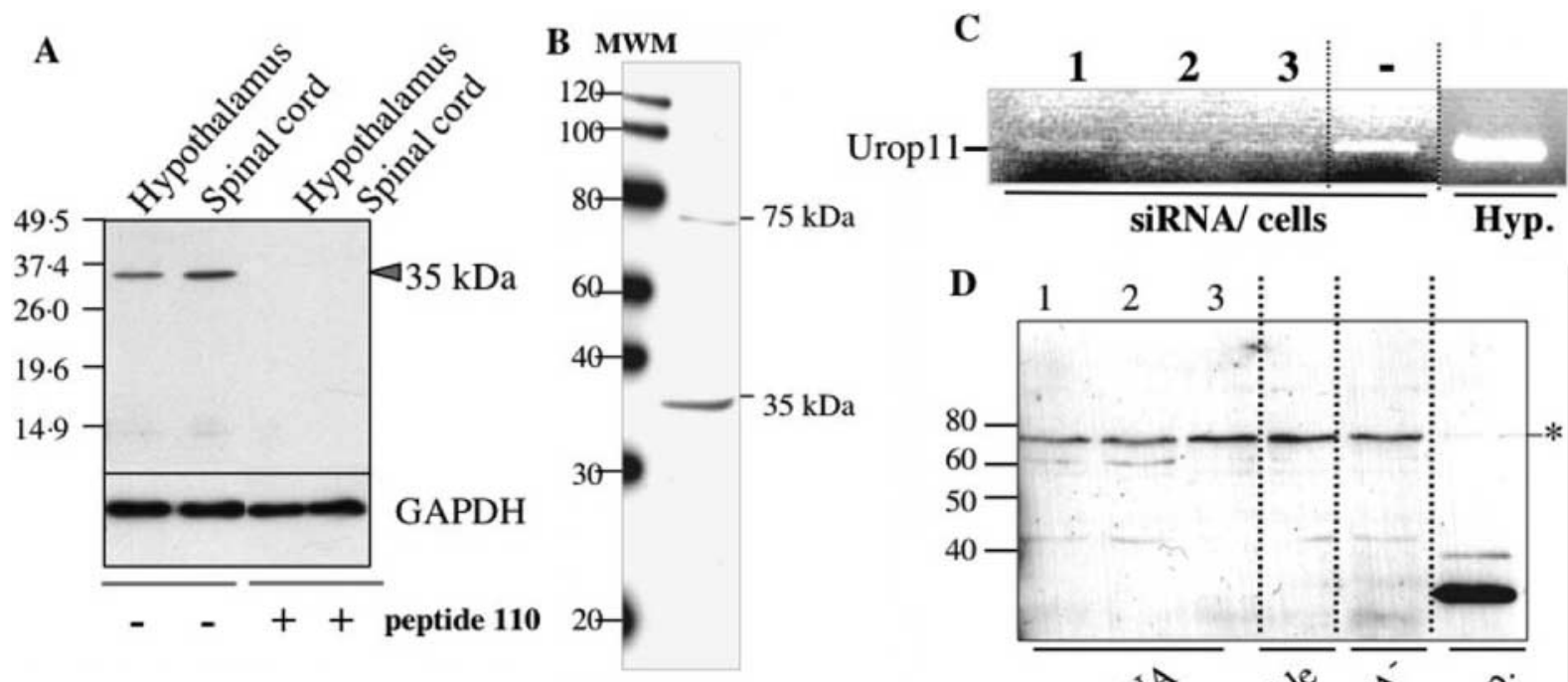

$\mathbf{E}$
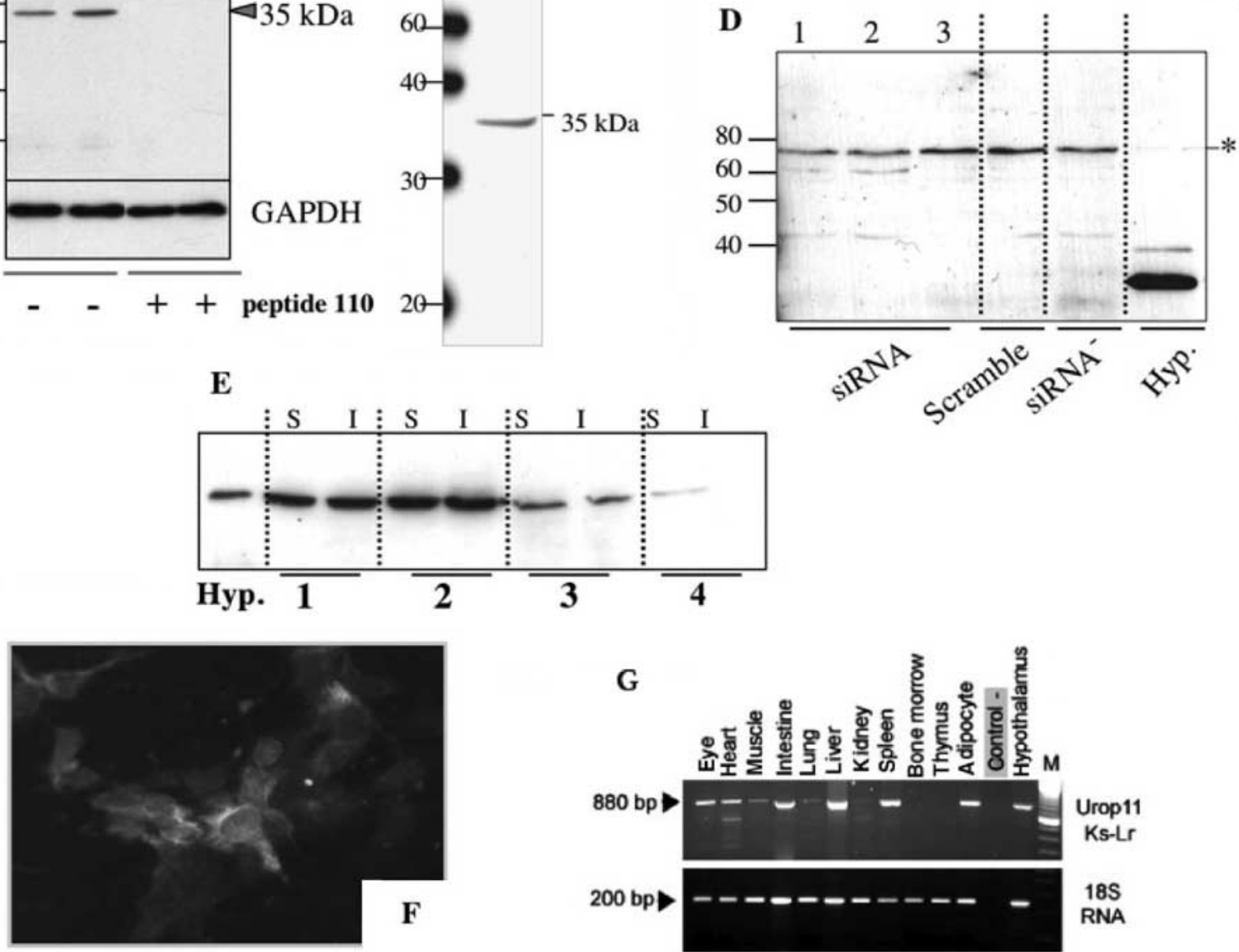

Figure 3 Identification of Urop11 protein. (A) Samples of hypothalamic and spinal cord cell lysates were subjected to SDS-PAGE and western blotting, with anti-Urop11-p110 antibodies (lanes 1 and 2 respectively). Lanes 3 and 4 show identical blots after preincubation of the antibody with the immunizing peptide, as described in Materials and methods. GAPDH was used as the internal control using an anti-GAPDH antiserum (Chemicon Temecula, CA, USA; 1:50 000 dilution). (B) Hypothalamic protein lysates were immunopurified (IP) using the rabbit polyclonal antibodies in non-denaturized conditions and the complex further purified onto agarose-protein G beads. The IP was then run on SDS gel; a major band at about $35 \mathrm{kDa}$ and a weak one at $75 \mathrm{kDa}$ could be visualized. (C) Detection of Urop11 mRNAs from mouse GT1-7 hypothalamic cells incubated with si-RNA silencing primers (1, 2, 3, see Materials and methods) when compared with the control primer (EtBr detection). The Urop11 mRNA product detected in the mouse brain exhibited the same size as in GT1-7 cells. (D) Western blot of cell lysates from GT1-7 hypothalamic cells incubated with (si)-RNAs targeted at the Urop11 coding sequence or a negative control duplex (scramble). The details for the three (si)-RNA duplexes (indicated as 1-3) are given in Materials and methods. (E) Western blot of Urop11 subcellular distribution. The extraction kit enables the differential extraction of proteins according to their localization: cytosolic proteins, membranes and organelles, solubilized nucleic proteins and cytoskeleton components (extracts 1, 2, 3, and 4 respectively), same protein amounts being loaded onto the gel. 'S' corresponds to the hypothalamus from sham-inoculated mouse and 'l' to the CDV-infected mouse 14 days after inoculation. (F) Urop11 protein at the cellular level using ICC, labeling being seen mainly in the cytoplasm and perinuclear area of GT1-7 cells. (G) Urop 11 mRNA expression analyzed in several peripheral tissues from Swiss mouse (PCR of 35 cycles $\left(94^{\circ} \mathrm{C}\right.$, $\left.\left.2 \mathrm{~min} / 60^{\circ} \mathrm{C}, 30 \mathrm{~s} / 72^{\circ} \mathrm{C}, 2 \mathrm{~min}\right)\right)$.

both central (spinal cord (see Fig. 5), olfactory bulb, and hippocampus (not shown)) and peripheral, such as spleen, liver, and adipocytes (Fig. 3G), as well as in the 3T3 mouse adipocyte cell line at both the immature and the mature states (data not shown). Thus, Urop11 expressed both by nervous, immune, and endocrine systems may represent a new actor in the crosstalk between these three systems. 


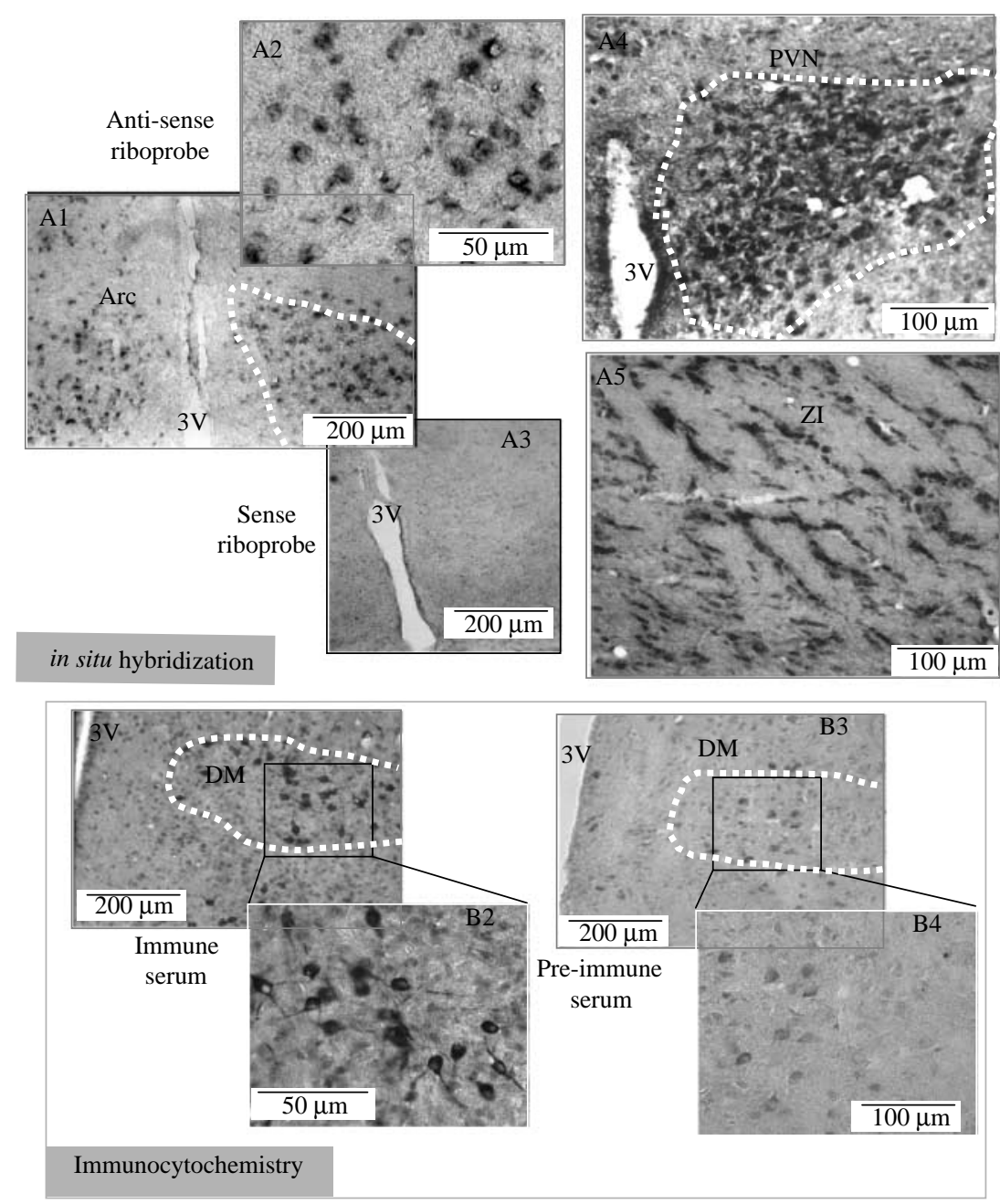

Figure 4 ISH and ICC brain localization of Urop11 mRNA and protein. (A) Urop11 mRNA was detected by ISH in neurons of the paraventricular (PVN) and arcuate (Arc) hypothalamic nuclei (A1, A2, and A4), mainly at the cytoplasmic level, while the cRNA sense sequence gave no signal (A3). An intense hybridization signal was also observed in cells with an oligodendrocyte phenotype (A5). (B) Labeling of hypothalamic neurons (B1) by rabbit anti-Urop11-p110 antibodies; a subset of neurons showed strong labeling (B2). Pre-immune serum gave no labeling (B3, B4).

\section{In vivo and in vitro Urop11 regulation}

Q-RT-PCR of hypothalamic mRNA of three infected obese mice (at 4,5, and $9 \mathrm{mpi}$ ) showed markedly higher Urop11 mRNA levels when compared with infected lean matched mice $(200,2000$, and 50\% higher respectively, Fig. 5A). However, when compared with sham-inoculated mice, a significant decrease in Urop11 expression was seen in infected mice during the acute stage of infection in the hypothalamus $(-58 \%, P<0 \cdot 05$ at $14 \mathrm{dpi}$ and $-66 \%, P<0.05$ at $16 \mathrm{dpi}$ ) and spinal cord $(-76 \%, P<0.01$ at $16 \mathrm{dpi}$; Fig. 5B). Interestingly, no change in Urop11 mRNA levels was seen before the beginning of viral replication (6 dpi, not shown), emphasizing the regulatory role of CDV infection in Urop11 expression. The relevance of Urop11 expression to obesity was also examined in the hypothalamus of non-virus induced obese mice $o b / o b$, $d b / d b$, and diet-induced obese mice (HFD; Moraes $e t a l$. 2003). Furthermore, the effect of leptin on Urop11 expression was assessed after leptin treatment of HFD mice and their controls (chow fed). Similar Urop11 mRNA levels were seen in untreated HFD mice $(n=5)$ and their age-matched controls $(n=7$; Fig. $5 \mathrm{C})$ and leptin treatment resulted in a significant increase in Urop11 expression both in HFD mice and their controls ( +94 and $+85 \%$ respectively, $P<0.05$; Fig. 5C), showing a positive regulatory effect of 

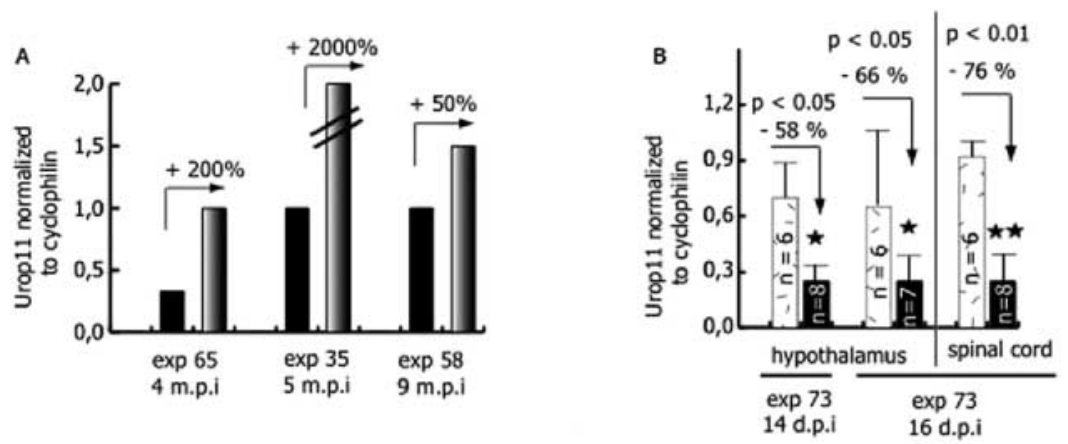

sham

CDV

obese

C

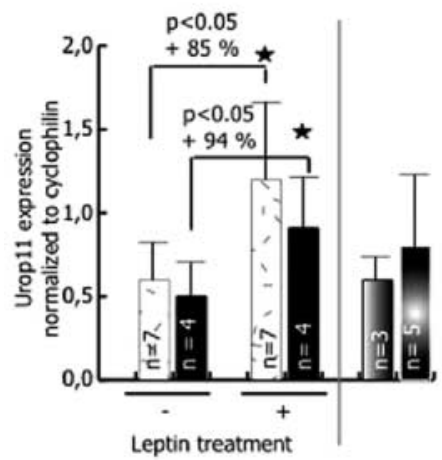

D

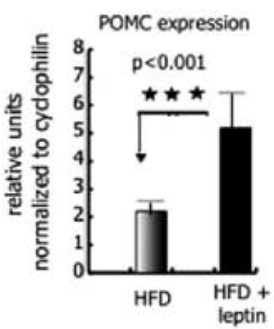

In-vivo
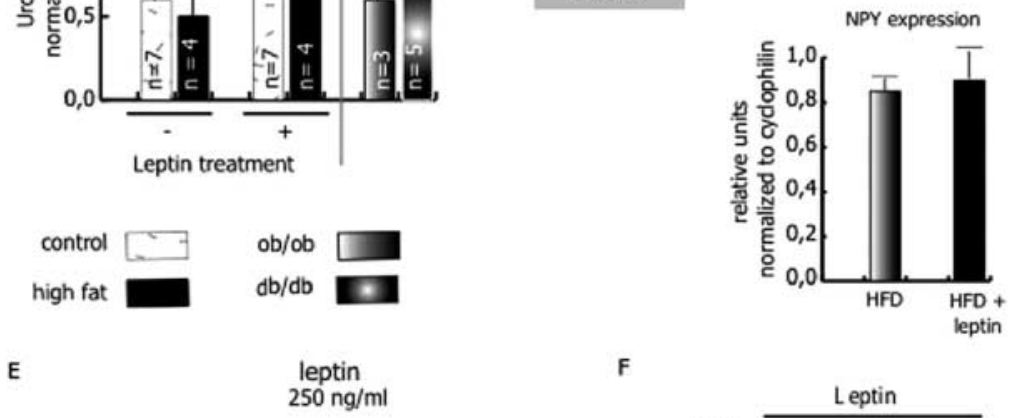

F
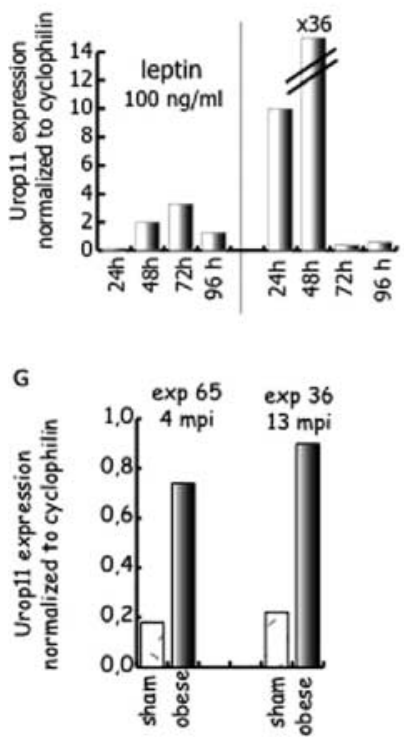
exogenous leptin on Urop11 expression, whereas in leptin-deficient $o b / o b(n=3)$ and leptin receptordeficient $\mathrm{db} / \mathrm{db}$ mice $(n=5)$, Urop11 expression seems to be identical to that in control mice $(n=7)$. Whereas, no change of neuropeptide Y (NPY) expression was observed in the hypothalamus from treated-HFD mice when compared with untreated HFD mice, we found that exogenous leptin is able to upregulate pro-opiomelanocortin (POMC) mRNA in treated-HFD mice (more than twofold; Fig. 5D). We also demonstrated that signal transducer and activator of transcription (STAT)-3 and suppressor of cytokine (SOC-1) expression were statistically upexpressed in the hypothalamus of leptin-treated HFD mice (Q-RT-PCR, results expressed as relative units normalized to the housekeeping gene $\mathrm{CyP}$, i.e. $0 \cdot 98 \pm$ $0 \cdot 02$ vs $0 \cdot 70 \pm 0 \cdot 09$, and $2 \cdot 38 \pm 0 \cdot 03$ vs $1 \cdot 81 \pm 0 \cdot 2$ respectively; $* P<0 \cdot 05)$. Our observations argue for the integrity of the leptin network in these mice and strongly support the action of the exogenous leptin on Urop11 expression and other genes located within the leptin cascade, even in mice exhibiting high endogenous leptin levels.

Given the likely in vivo regulation of Urop11 gene expression by leptin, in vitro analysis of Urop11 mRNA expression was performed on the N1E115 neuroblastoma cell line after $24-96 \mathrm{~h}$ of leptin treatment. As shown in Fig. 5E, Urop11 mRNA expression was increased at both concentrations of leptin used (100 or $250 \mathrm{ng} / \mathrm{ml}$ ), the increase being much greater at the higher dose (up to 36-fold when compared with no leptin treatment). Similar modulation of Urop11 mRNA expression was observed in the hypothalamic neuronal cell line GT1-7, with a $60 \%$ increase following treatment with $100 \mathrm{ng} / \mathrm{ml}$ leptin (data not shown). In both cell lines, an increase was also seen at the protein level (shown for GT1-7 in Fig. 5F). In summary, several in vitro experiments were performed using analyzing Urop11 mRNA and protein expression in N1E115 and GT1-7 cell lines (Fig. 5), as well as C8S (an astrocytoma cell line), 3T3 cell line, and hypothalamic slice cultures under leptin treatment. We found that leptin was able to upregulate Urop11 in a dose-dependent manner in these cell cultures. All together these in vitro and in vivo data (mice $n=11$; i.e. seven chow fed and four HFD mice), undoubtedly highlighted that leptin acts onto Urop11 expression.

Theses results suggest (i) direct or indirect regulation of Urop11 mRNA expression either by CDV or by the inflammatory process occurring during the acute stage of infection (Khuth et al. 2001), (ii) the association of Urop11 mRNA expression with the virally induced obesity status and aging, (iii) the possibility that Urop11 mRNA might be used as a CDV-induced obesity marker in asymptomatic mice which have survived encephalitic disease and are on the way to becoming obese.

Urop11 mRNA was also detected in human peripheral blood leukocytes (PBL) and lymphoid cell lines (C8166, C91PL, MT4, CEM), and at especially high levels in Dev cells, a human neural precursor cell line (RT-PCR; Fig. 6A), the same Tm for the mouse and human products demonstrated the similitude between these two amplified transcripts (Fig. 6B). Anti-Urop11-p110 antibodies revealed a single band in human samples, but the difference between Urop11 molecular weight in the mouse hypothalamus $(35 \mathrm{kDa})$ and that in human samples (75 kDa, apparent molecular weight), also observed in mouse cell cultures, is to date unexplained.

Figure 5 In vivo and in vitro regulation of Urop11 expression. (A) Q-RT-PCR analysis performed on hypothalamic RNA of three obese mice and infected-lean mice confirmed the upregulation of Urop 11 mRNA expression seen by RNB (200, 2000, and 50\% increase normalized to cyclophilin (CyP) mRNA levels in experiment 65, 35, or 58 respectively). (B) Q-RT-PCR analysis of Urop11 mRNA expression during the acute stage of CDV infection on hypothalamus of sham-inoculated and CDV-infected mice (14 dpi) and hypothalamus and spinal cord of sham-inoculated and CDV-infected mice (16 dpi), expression being normalized to CyP mRNA levels. Downregulation of Urop11 mRNA was observed in the hypothalamus of CDV-infected mice during the acute stage of infection when compared with sham-inoculated mice at $14 \mathrm{dpi}(58 \%, P<0.05, n=8)$ and $16 \mathrm{dpi}(66 \%, P<0.05, n=7$; control $n=6$ in both) and in the spinal cord at $16 \mathrm{dpi}(76 \%, P<0.01, n=8$ versus control $n=6)$. (C) Urop11 mRNA expression in the hypothalamus of untreated control, HFD ( $n=7$ in both), leptin deficiency ob/ob $(n=3)$, and leptin receptor-deficient $\mathrm{db} / \mathrm{db}(n=4)$ mice and of leptin-treated control and HFD mice $(n=4$ in both). The numbers indicate the percentage upregulation. No difference was observed between Urop11 mRNA levels in the hypothalamus of control and HFD mice by Q-RT-PCR analysis, expression being strongly upregulated in controls $(+85 \%$; $P<0.05)$ or HFD mice $(+94 \%, P<0.05)$ after leptin treatment. No change was seen in the hypothalamus of leptin deficiency obese ob/ob mice $(n=3)$ and leptin receptor-deficient $\mathrm{db} / \mathrm{db}$ mice $(n=4)$. (D) NPY and POMC mRNA expression analysis were performed on hypothalamus from untreated and leptin-treated HFD mice (see Materials and methods) using Q-RT-PCR. Results are expressed as relative units normalized to the housekeeping gene CyP. PCR was realized on the same RT product used for Urop 11 expression analysis (statistical Student's $t$ test). (E) Effect of the leptin treatment on Urop11 mRNA levels in N1E115 cells: N1E115 cells were incubated with recombinant leptin (100 or $250 \mathrm{ng} / \mathrm{ml}$ ) and Urop11 mRNA analyzed using Q-RT-PCR. Urop11 was upregulated as early as 24-h culture with $250 \mathrm{ng} / \mathrm{ml}$ leptin, upregulation being stronger at $48 \mathrm{~h}(3600 \%)$. Moderate upregulation was also seen with a lower dose of leptin. (F) Effect of the leptin treatment on Urop11 protein expression in GT1-7 hypothalamic cells. Western blot analysis was performed onto cell lysates (40 $\mu \mathrm{g}$ in each lane) using rabbit antibodies anti Urop 11 (1:400) and peroxidase-conjugated goat anti-rabbit IgG (1:50 000). (G) Urop11 mRNA expression is strongly upregulated in adipocyte from obese mice (4 and $13 \mathrm{mpi}$ ) when compared with sham-inoculated animals (roughly $300 \%$ ), indicating a modification of Urop11 expression in tissue other than in brain. 

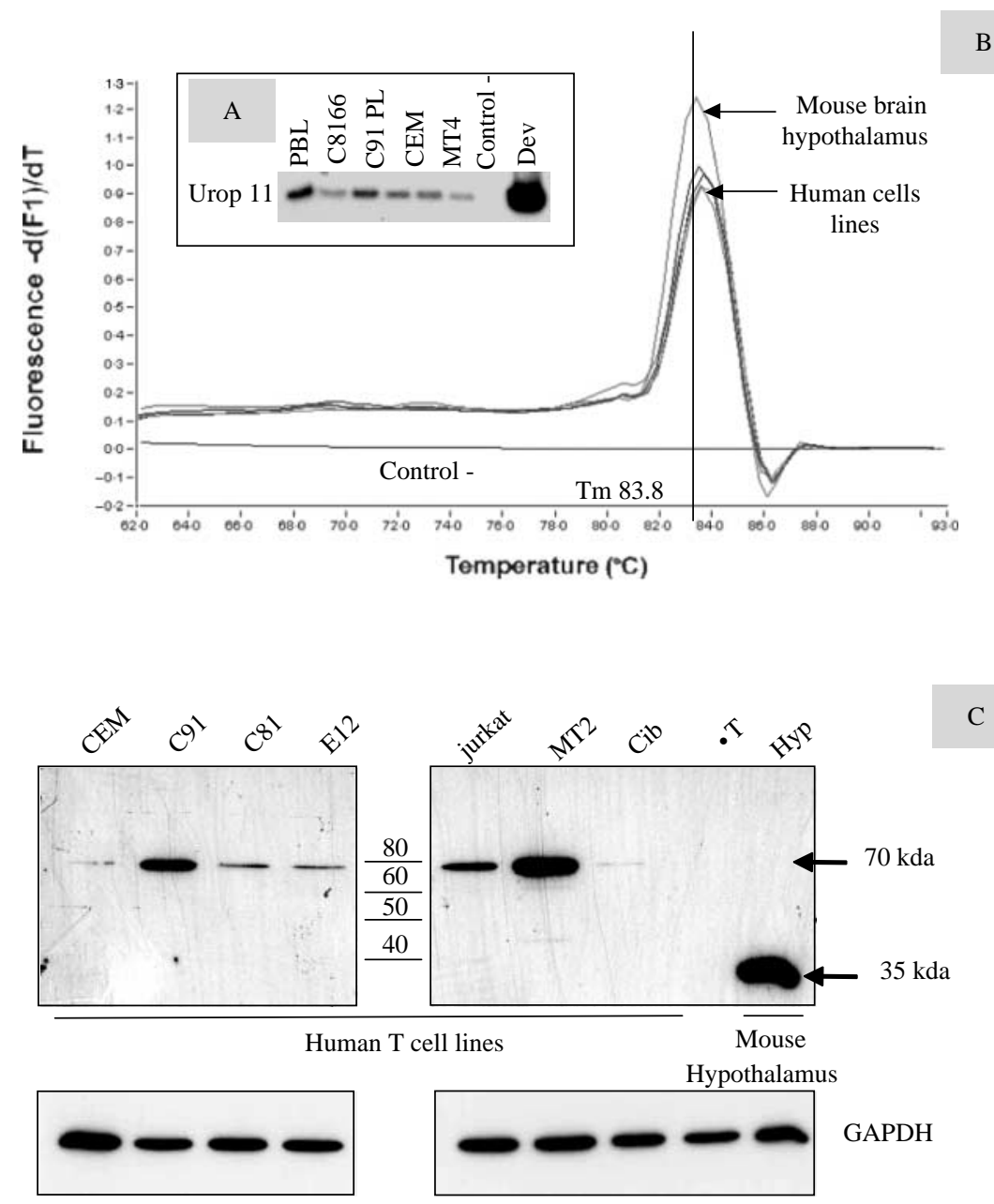

Figure 6 Urop11 expression in human samples. (A) End-point PCR was performed in several human T lymphocyte cell lines and neural cell line (Dev) and amplicons hybridized with an internal ${ }^{32} \mathrm{P}$-labeled probe. A strong signal of the expected size was seen in Dev cells and, to a lesser extent, in PBL and the T cell lines, C8166, C91PL, CEM, and MT2. (B) Identification of Urop11 mRNA was assessed by Q-RT-PCR as Tm of DNA products from human samples and mouse hypothalamus $\left(83.8^{\circ} \mathrm{C}\right)$ was similar. (C) Accuracy of Urop 11 protein was proved in $\mathrm{T}$ human cell lines by western blots $(20 \mu \mathrm{g}$ proteins) using rabbit antibodies against Urop11 (1:1000) and peroxidase-conjugated goat anti-rabbit IgG (1:50 000). A single $75 \mathrm{kDa}$ band was seen; the strongest labeling being observed in activated cell lines (MT2, C91), and to a lesser extent in quiescent cell lines (C8666 and E12). Similar loading was demonstrated by detection of GAPDH (monoclonal antibodies 1:50 000) and peroxidase-conjugated anti mouse serum (1:20 000) on the same membrane.

Urop11 expression in human cell lines seemed to correlate with the state of activation, being very high in activated $\mathrm{T}$ lymphocytes (C91PL and MT2), low in quiescent cell lines (CEM and $\mathrm{T}$ lymphocytes), and intermediate in weakly activated cell lines (Jurkat, C8166, and E12).

In conclusion, the molecular data for Urop11, its presence both in neurons, oligodendrocytes, lymphoid cells, and adipocytes, and its regulation by leptin, argue for a specific role of this newly identified protein in the neuro-endocrino-immune pathway.

\section{Discussion}

We previously reported that, during the early stage of infection, CDV predominantly targets neurons in the mouse hypothalamus (Bernard et al. 1993) and we hypothesized that obesity syndrome associated with persistence of a low level of virus in the hypothalamus could be due to specific neuronal loss and/or epigenetic alteration of hypothalamic genes involved in food intake, energy control, and basal metabolism. Our mouse model of obesity allowed us to demonstrate 
that a virus could induce marked disturbance of gene expression in the neural network responsible for energy homeostasis (Harrold 2004), emphasizing the overlooked possibility of viral infection in the etiology of obesity (Dhurandhar 2001). To discover new candidate genes of central energy homeostasis that are altered in CDV-induced obesity, we used SSH in order to characterize the pattern of cellular gene responses to CDV infection and identified several differentially expressed cDNAs. Of these, we focused on a new gene associated with mouse obesity, which we named Urop11, and determined its full-length nucleotide sequence, its predicted protein sequence, and chromosome localization, and demonstrated its functional relevance in the leptin network.

\section{Urop11 is a new gene that is dramatically upregulated in the hypothalamus of virus-induced obese mice}

In this study, we cloned Urop11, a gene strongly expressed in the hypothalamus of infected obese mice. Whatever the library used, we did not find any similarities with known messengers, anonymous sequences (EST), or computational predicted genes, suggesting that Urop11 could be the product of a hitherto unknown gene. A Blast search against the mouse genome localized the complete Urop11 sequence on chromosome 19. Alignment of the longest isolated Urop11 sequence with the mouse genome mining data led to its localization in the fourth intron of the predicted gene, inside the fourth intron of the $A B P A 1$ gene. Even if we cannot exclude the possibility that the Urop11 gene is composed of several exons, we know that the coding part of Urop11 mRNA is located in a single unspliced exon, as the isolated sequence perfectly matched the genomic sequence of the Apbal intron. Since Urop11 cDNA expression was still detected after efficient DNase treatment, we assumed that it did not represent genomic contamination, but rather a true messenger with a weak transcriptional level, as northern blot analysis showed very weak labeling. Several additional lines of evidence suggested the existence of Urop11 mRNA. First, two polyadenylation sites were identified close to the $3^{\prime}$ end of the isolated cDNA sequence, and bioinformatic analysis identified a 110 amino acid ORF with a partial Kozak consensus sequence. Expression of this ORF was verified through the identification, in the hypothalamus and several other brain structures, of a major protein of $35 \mathrm{kDa}$ on western blots, labeling of which was abolished when the anti-Urop11 antibodies were pre-adsorbed with the immunizing peptide or following (si)-RNAs interference. Secondly, bioinformatic analysis of the genomic sequence slightly upstream of the $5^{\prime}$ end of the Urop11 cDNA allowed the localization, with high probability, of several transcriptional starting points for Pol II, several contigs-assembly and annotation tool (CAAT) boxes, and many transcriptional factor consensus sequences in the same limited genomic area. Functional characterization of the Urop11 promoter sequence by sequential deletion will be the subject of future studies, to definitely locate the transcriptional start point and to determine the functional role of Urop11. As with Urop11 mRNA, the deduced Urop11 protein sequence showed no similarity with any protein in protein data libraries. Computational structural analysis revealed several possible post-translational modification sites (phosphorylation, myristoylation, and glycosylation sequences), which probably account for the larger apparent molecular weight of the expressed protein.

Interestingly, using the computational tool, DisEMBL, we were able to detect three disordered regions ('hot loops') inside the Urop11-p110 sequence. Although little is known about the cellular and structural meaning of intrinsically disordered proteins, they are thought to become ordered only when they are bound by another molecule or as a result of changes in the biochemical environment, this disordered state allowing more interaction with partners and an increase in protein functions without affecting the genome size (Dunker et al. 2002, Gunasekaran et al. 2003, 2004). It has also recently been demonstrated that protein disorder plays a central role in biology and diseases caused by protein mis-folding and aggregation (Kaplan et al. 2003). It is now well established that the eukaryotic genome codes for a high proportion of intrinsically unstructured proteins that are often involved in signalizing processes and implicated in severe neurodegenerative diseases. In our study, we show that Urop11 is expressed in several central and peripheral tissues, and in numerous cell types, suggesting several possible physiological roles. Regulation of its expression exclusively in hypothalamic neurons and adipocytes from obese mice emphasized the link between the Urop11 and the pathological process. Further studies will be needed to understand these different roles and the hypothetical relationship of Urop11-p110 with ABPA1 protein.

\section{The Urop11 hypothalamic gene is involved in the leptin response network}

Both in vivo and in vitro analyses showed that Urop11 expression was regulated by leptin. Urop11 mRNA expression showed a strong dose-dependent increase in leptin-treated mice and in leptin-treated cultured neural cells. Leptin is an adipokine (Zhang et al. 1997) that conveys information on energy availability, influences energy homeostasis, and regulates 
neuroendocrine function primarily in states of energy deficiency through the functional leptin receptor $(\mathrm{Ob}-$ $\mathrm{Rb}$; Mercer et al. 1996, Elmquist et al. 1998). Ob-Rb, which belongs to the class I cytokine receptor family (Baumann et al. 1996), acts via both the Janus kinase/ STAT pathway and the mutagen activated protein kinase (MAPK) pathway (Fruhbeck 2006). Although $\mathrm{Ob}-\mathrm{Rb}$ mediates leptin action, access to this receptor on target cells is also influenced by the truncated leptin receptor isoforms, Ob-Ra and Ob-Re (Smith et al. 2005). These recent data suggest that the actions of leptin depend not only on its synthesis in adipose tissue and Ob-Rb expression in target cells, but also on factors that regulate tissue expression of $\mathrm{Ob}-\mathrm{Re}$, and thus leptin transport in the plasma (Hileman et al. 2002). Intriguingly, exogenous leptin upregulated Urop11 in the hyperleptinemic HFD mice. Nevertheless, we can assert the integrity of the leptin network as the expression of genes located downstream of the leptin receptor action are modified, such as POMC, STAT-3, and SOC-1 known to be leptin targets (Ghilardi et al. 1996, Vaisse et al. 1996). The absence of NPY responsiveness in leptin-treated HFD mice could be explained by an alteration of the loop system between NPY and leptin in obese mice, as suggested by Rohner-Jeanrenaud et al. (1996). On the other hand, the dramatic upregulation of Urop11 expression in the hypothalamus of obese CDV-infected mice, in which the $\mathrm{Ob}-\mathrm{Rb}$ is markedly strongly downregulated (Bernard $e t$ al. 1999), suggests direct negative control of $\mathrm{Ob}-\mathrm{Rb}$ on Urop11 gene expression; it is probable that a functional leptin receptor is not absolutely required for this effect. Urop11 might therefore represent a new intermediate element in the leptin pathway. Further studies are required to determine whether it plays a positive or a negative role, like Socs-3, a negative leptin regulator (Howard et al. 2004), and to determine whether regulation of $\mathrm{Ob}-\mathrm{Rb}$ and Urop11 occurs in the same cell. The expression of Urop 11 mRNA and protein in a subset of hypothalamic neurons indicates that this novel gene might be involved in the regulation of the energy homeostasis network. Moreover, the expression of Urop11 in mouse adipocytes and lymphocytes suggests it may be involved in neural/endocrine/ immune system crosstalk. The identification at the molecular level of the mechanisms by which Urop11 functions might provide new approaches to pharmaceutical targeting aimed at modulating the intracellular effects of leptin.

\section{Acknowledgements}

We thank Professor Jean Paul Riou for advice and stimulating discussion. We are grateful to Tom Barkas for critical evaluation of the English.

\section{Funding}

This work was supported by grants from INSERM-INRA, The Rhone Alpes Region and Inserm funds. The authors declare that there is no conflict of interest that would prejudice the impartiality of this scientific work.

\section{References}

Amano T, Richelson E \& Nirenberg M 1972 Neurotransmitter synthesis by neuroblastoma clones. PNAS 69 258-263.

Bajic VB, Seah SH, Chong A, Zhang G, Koh JL \& Brusic V 2002 Dragon Promoter Finder: recognition of vertebrate RNA polymerase II promoters. Bioinformatics 18 198-199.

Baumann H, Morella KK, White DW, Dembski M, Bailon PS, Kim H, Lai CF \& Tartaglia LA 1996 The full-length leptin receptor has signaling capabilities of interleukin 6-type cytokine receptors. PNAS 93 8374-8378.

Bencsik A, Akaoka H, Giraudon P, Belin MF \& Bernard A 1997 Inhibition of tyrosine hydroxylase expression within the substantia nigra of mice infected with canine distemper virus. Journal of Neuropathology and Experimental Neurology 56 673-685.

Bernard A, Wild TF \& Tripier MF 1983 Canine distemper infection in mice: characterization of a neuroadapted virus strain and its longterm. Journal of General Virology 64 1571-1579.

Bernard A, Fèvre-Montange M, Bencsik A, Giraudon P, Wild TF, Confavreux C \& Belin MF 1993 Brain structures selectively targeted by canine distemper virus in a mouse model infection. Journal of Neuropathology and Experimental Neurology 52 471-480.

Bernard A, Cohen R, Khuth ST, Vedrine B, Verlaeten O, Akaoka H, Giraudon P \& Belin MF 1999 Alteration of the leptin network in late morbid obesity induced in mice by brain infection with canine distemper virus. Journal of Virology 73 7317-7327.

Dhurandhar NV 2001 Infectobesity: obesity of infectious origin. Journal of Nutrition 131 2794-2797.

Dhurandhar NV, Kulkarni PR, Ajinkya SM, Sherikar AA \& Atkinson RL 1997 Association of adenovirus infection with human obesity. Obesity Research 5 464-469.

Dhurandhar NV, Israel BA, Kolesar JM, Mayhew GF, Cook ME \& Atkinson RL 2000 Increased adiposity in animals due to a human virus. International Journal of Obesity and Related Metabolic Disorders $\mathbf{2 4}$ 989-996.

Dhurandhar NV, Whigham LD, Abbott DH, Schultz-Darken NJ, Israel BA, Bradley SM, Kemnitz JW, Allison DB \& Atkinson RL 2002 Human adenovirus Ad-36 promotes weight gain in male rhesus and marmoset monkeys. Journal of Nutrition 132 3155-3160.

Diatchenko L, Lau YF, Campbell AP, Chenchik A, Moqadam F, Huang B, Lukyanov S, Lukyanov K, Gurskaya N, Sverdlov ED et al. 1996 Suppression subtractive hybridization: a method for generating differentially regulated or tissue-specific cDNA probes and libraries. PNAS 93 6025-6030.

Dunker AK, Brown CJ, Lawson JD, Iakoucheva LM \& Obradovic Z 2002 Intrinsic disorder and protein function. Biochemistry 41 6573-6582.

Elmquist JK, Ahima RS, Elias CF, Flier JS \& Saper CB 1998 Leptin activates distinct projections from the dorsomedial and ventromedial hypothalamic nuclei. PNAS 95 741-746.

Elmquist JK, Coppari R, Balthasar N, Ichinose M \& Lowell BB 2005 Identifying hypothalamic pathways controlling food intake, body weight, and glucose homeostasis. Journal of Comparative Neurology $49363-71$.

Fruhbeck G 2006 Intracellular-signaling pathways activated by leptin. Biochemical Journal 393 7-20. 
Ghilardi N, Ziegler S, Wiestner A, Stoffel R, Heim MH \& Skoda RC 1996 Defective STAT signaling by the leptin receptor in diabetic mice. PNAS 93 6231-6235.

Griffond B, Verlaeten O, Belin MF, Risold PY \& Bernard A 2004 Canine distemper virus infection of the central nervous system alters expression of hypothalamic neuropeptides during the acute encephalitis: relevance to the late-onset obesity. Brain Research 1022 173-181.

Gunasekaran K, Tsai C, Kumar S, Zanuy D \& Nussinov R 2003 Extended disordered proteins: targeting function with less scaffold. Trends in Biochemical Sciences 28 81-85.

Gunasekaran K, Tsai CJ \& Nussinov R 2004 Analysis of ordered and disordered protein complexes reveals structural features discriminating between stable and unstable monomers. Journal of Molecular Biology 341 1327-1341.

Harrold JA 2004 Hypothalamic control of energy balance. Current Drug Targets 5 207-219.

Herden C, Herzog S, Richt JA, Nesseler A, Christ M, Failing K \& Frese K 2000 Distribution of Borna disease virus in the brain of rats infected with an obesity-inducing virus strain. Brain Pathology 10 39-48.

Hileman SM, Pierroz DD, Masuzaki H, Bjorbaek C, El-Haschimi K, Banks WA \& Flier JS 2002 Characterization of short isoforms of the leptin receptor in rat cerebral micro vessels and of brain uptake of leptin in mouse models of obesity. Endocrinology 143 775-783.

Howard JK, Cave BJ, Oksanen LJ, Tzameli I, Bjorbaek C \& Flier JS 2004 Enhanced leptin sensitivity and attenuation of diet-induced obesity in mice with haploinsufficiency of Socs3. Nature Medicine $\mathbf{1 0}$ 734-738.

Kaplan B, Ratner V \& Hass E 2003 Alpha-synuclein: its biological function and role in neurodegenerative disease. Journal of Molecular Neuroscience 20 83-92.

Khuth ST, Akaoka H, Pagenstecher A, Verlaeten O, Belin MF, Giraudon P \& Bernard A 2001 Morbillivirus infection of the mouse central nervous system induces region-specific upregulation of MMPs and TIMPs correlated to inflammatory cytokine expression. Journal of Virology 75 8268-8282.

Knudsen S 1999 Promoter2.0: for the recognition of Pol II promoter sequences. Bioinformatics 15 356-361.

Lyons K \& Nagashima JB 2002 Animal models of post-infectious obesity: hypothesis and review. Journal of Neurovirology 8 1-5.

Mellon PL, Windle JJ, Goldsmith PC, Roberts JL \& Weiner RI 1990 Immortalization of GnRH neurons by genetically targeted tumorigenesis. Neuron 5 1-10.

Mercer JG, Hoggard N, Williams LM, Lawrence CB, Hannah LT \& Trayhurn P 1996 Localization of leptin receptor mRNA and the long form splice variant (Ob-Rb) in mouse hypothalamus and adjacent brain regions by in situ hybridization. FEBS Letter 387 113-116.

Moraes RC, Blondet A, Birkenkamp-Demtroeder K, Tirard J, Orntoft TF, Gertler A, Durand P, Naville D \& Begeot M 2003 Study of the alteration of gene expression in adipose tissue of diet-induced obese mice by micro array and reverse transcription-polymerase chain reaction analyses. Endocrinology 144 4773-4782.

Pedersen AG \& Nielsen H 1997 Neural network prediction of translation initiation sites in eukaryotes: perspectives for EST and genome analysis. Proceedings of the International Conference on Intelligent Systems for Molecular Biology 5 226-233.

Reese MG 2001 Application of a time delay neural network to promoter annotation in the Drosophila melanogaster genome. Computers and Chemistry 26 51-56.

Rohner-Jeanrenaud F, Cusin I, Sainsbury A, Zakrzewska KE \& Jeanrenaud B 1996 The loop system between neuropeptide Y and leptin in normal and obese rodents. Hormone and Metabolic Research 28 642-648.

Sandberg MK \& Low P 2005 Altered interaction and expression of proteins involved in neurosecretion in scrapie-infected GT1-1 cells. Journal of Biological Chemistry 280 1264-1271.

Smith JT, Mark PJ \& Waddell BJ 2005 Developmental increases in plasma leptin binding activity and tissue Ob-Re mRNA expression in the rat. Journal of Endocrinology 184 535-541.

Szymocha R, Brisson C, Bernard A, Akaoka H, Belin MF \& Giraudon P 2000 Long-term effects of HTLV-1 on brain astrocytes: sustained expression of Tax-1 associated with synthesis of inflammatory mediators. Journal of Neurovirology 6 350-357.

Vaisse C, Halaas JL, Horvath CM, Darnell JE Jr, Stoffel M \& Friedman JM 1996 Leptin activation of Stat3 in the hypothalamus of wild-type and $o b / o b$ mice but not $d b / d b$ mice. Nature Genetics 14 95-97.

Verlaeten O, Griffond B, Khuth ST, Giraudon P, Akaoka H, Belin MF, Fellmann D \& Bernard A 2001 A downregulation of melanin concentrating hormone in virally induced obesity. Molecular and Cellular Endocrinology 181 207-219.

Wetsel WC, Mellon PL, Weiner RI \& Negro-Vilar A 1991 Metabolism of pro-luteinizing hormone-releasing hormone in immortalized hypothalamic neurons. Endocrinology 129 1584-1595.

Zhang F, Basinski MB, Beals JM, Briggs SL, Churgay LM, Clawson DK, DiMarchi RD, Furman TC, Hale JE, Hsiung HM et al. 1997 Crystal structure of the obese protein leptin-E100. Nature $\mathbf{3 8 7}$ 206-209.

Received 10 October 2006

Accepted 18 October 2006 